\title{
Helium isotopic composition of hydrothermal fluids from the Manus back-arc Basin, Papua New Guinea
}

\author{
E. Fourre, ${ }^{1}$ P. Jean-Baptiste, ${ }^{1 *}$ J.-L. Charlou,${ }^{2}$ J. P. Donval ${ }^{2}$ and J. I. Ishibashi ${ }^{3}$ \\ ${ }^{1}$ IPSL/LSCE, UMR CEA-CNRS 1572, CEA/Saclay, 91191 - Gif-sur-Yvette cedex - France \\ ${ }^{2}$ IFREMER, DRO-GM, Centre de Brest, BP 70, 29280 - Plouzané - France \\ ${ }^{3}$ Department of Earth \& Planetary Sciences, Kyushu University, Fukuoka 812-8581, Japan
}

(Received April 25, 2005; Accepted November 21, 2005)

\begin{abstract}
We present isotopic analysis of helium in hydrothermal fluids from the Manus back-arc basin, collected during the French-Japanese Manusflux and Manaute cruises in 1995 and 2000, respectively. The helium isotope composition of the fluids is comparable to that measured elsewhere in similar subduction environments, with ${ }^{3} \mathrm{He} /{ }^{4} \mathrm{He}$ values $\left(7.4\right.$ to $\left.7.9 \mathrm{R}_{\mathrm{a}}\right)$ slightly lower than typical MORB values, except on the Manus Spreading Center (MSC) where higher values ( $12 \pm 0.1 \mathrm{R}_{\mathrm{a}}$ ) are observed. The causal link between the narrow spatial extent of the ${ }^{3} \mathrm{He} /{ }^{4} \mathrm{He}$ anomaly at the MSC and a ${ }^{3} \mathrm{He}-\mathrm{rich}$ deep mantle component remains elusive, based on available geophysical data. Thus, the Manus Spreading Center results may be an interesting example of small scale upper-mantle heterogeneity.
\end{abstract}

Keywords: helium isotopes, hydrothermal fluids, back-arc basins, Manus Basin, western Pacific

\section{INTRODUCTION}

The Manus Basin is located in the Eastern Bismark sea (Fig. 1). It is one of the intra-arc, or back-arc basins, aligned along the boundary between the Australian and Pacific plates. Regional tectonics show it is bounded to the north by the inactive Manus Subduction Zone and to the south by the tectonically active New Britain arc-trench system (Fig. 1). Spreading (or stretching) occurs on three ridge segments offset by transform faults: the Western Spreading Rift (WSR), the Manus Spreading Center (MSC), and the Southeastern Ridges (SER). The supply of volcanic material and hydrothermal activity are not restricted to the spreading axes but are distributed among numerous volcanoes: the hydrothermal sites discovered in the area span a range of thermal regimes from lowtemperature shimmering waters to high-temperature fluids, with contrasting chemical compositions ranging from hydrothermal fluids typical of basaltic environments, to sulfate-rich highly acidic fluids (Gamo et al., 1997).

Here, we report helium isotope results for hydrothermal fluids from the Manus Basin, collected by the Shinkai 6500 and Nautile submersibles during the 1995 Manusflux and 2000 Manaute cruises. Both cruises were part of the Japanese-French New Starmer project aimed at explor-

*Corresponding author (e-mail: Philippe.Jean-Baptiste@cea.fr)

Copyright $@ 2006$ by The Geochemical Society of Japan. ing the Manus Basin ridge segments (Auzende et al., 2000). Helium isotopes provide a means for tracing the signature of the Earth's major reservoirs. ${ }^{4} \mathrm{He}$ is the product of $\mathrm{U}$ and $\mathrm{Th}$ radioactive decay whereas ${ }^{3} \mathrm{He}$ is essentially primordial in origin. Volatiles derived from midocean ridges display rather uniform ${ }^{3} \mathrm{He} /{ }^{4} \mathrm{He}$ values equal to $8 \pm 1 \mathrm{R}_{\mathrm{a}}$ (where $\mathrm{R}_{\mathrm{a}}$ is the ratio in air $=1.38 \times 10^{-6}$ ). This value is considered a characteristic signature of the upper mantle. Plume-related ocean islands, such as Hawaii and Iceland are enriched in ${ }^{3} \mathrm{He}$ with ${ }^{3} \mathrm{He} /{ }^{4} \mathrm{He}$ values up to $\sim 40 \mathrm{R}_{\mathrm{a}}$. Most hypotheses suggest that the high ${ }^{3} \mathrm{He} /$ ${ }^{4} \mathrm{He}$ values have their origin in the relatively undegassed lower mantle. Conversely, crustal ${ }^{3} \mathrm{He} /{ }^{4} \mathrm{He}$ values are significantly lower than that for air due to the production of radiogenic ${ }^{4} \mathrm{He}$. Thus, in a tectonically complex environment such as the Manus Basin, the helium isotope ratio $\left({ }^{3} \mathrm{He} /{ }^{4} \mathrm{He}\right)$ is a tracer of the origin of arc-magmas that interact with hydrothermal fluids and therefore may provide information on the relative contribution of the mantle, the subducting slab, and the local crust to magmatic processes.

\section{HYDROTHERMAL SITES}

Fluids from active hydrothermal sites were collected from several locations along the three ridge system which strikes from east to west across the Manus Basin (Fig. 1). Some of the study sites were known previously with others discovered during the New Starmer project. 


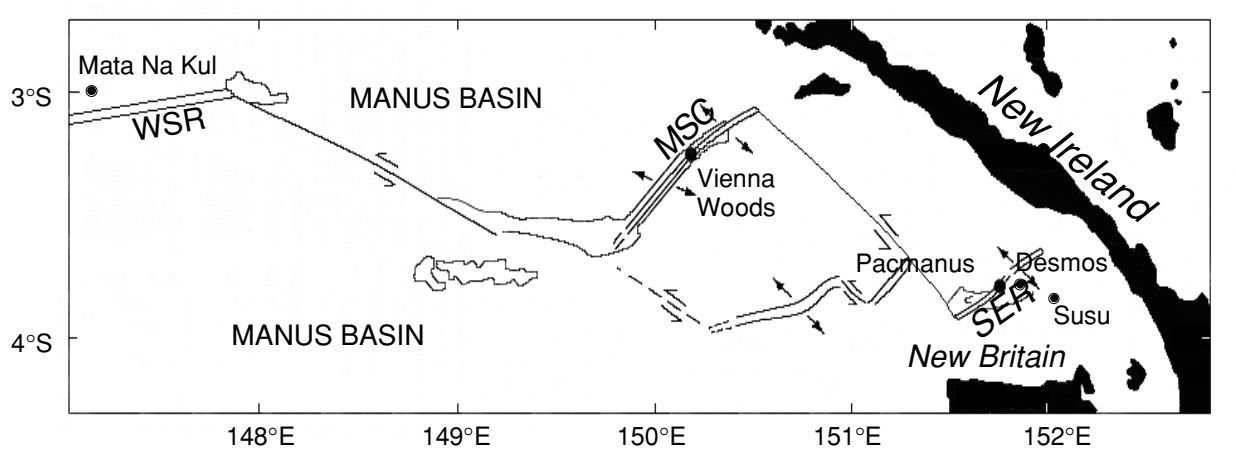

Fig. 1. Geological setting of the Eastern Bismarck Sea and Manus Basin.

\section{The South Eastern Rift (SER)}

The SER is a complex system of ridges, more akin to an extensional zone than to a typical oceanic spreading center. Hydrothermal activity on the SER was first detected from water column anomalies of methane and ${ }^{3} \mathrm{He}$ during the 1986 Papatua expedition (Craig et al., 1987) and confirmed later from large $\mathrm{CH}_{4}$ and $\mathrm{Mn}$ anomalies (Gamo et al., 1993) centered over the Desmos caldera. Another active site (Pacmanus field) was identified 20 $\mathrm{km}$ west of Desmos by dredging and bottom photography (Binns and Scott, 1993). Both sites were visited during the 1995 Manusflux and 2000 Manaute cruises where intense hydrothermal activity was observed. In addition, a third active area (the Susu site) was discovered during the Manaute cruise south east of Desmos (Fig. 1).

The Desmos caldera $\left(3^{\circ} 42.0^{\prime} \mathrm{S}, 151^{\circ} 52.3^{\prime} \mathrm{E}\right)$ is an offaxis structure located on a transverse fault parallel to the Djaul and Weitin Fracture Zones. It is $1.5 \mathrm{~km}$ in diameter and its maximum depth is $2110 \mathrm{~m}$ with walls up to $285 \mathrm{~m}$ high. Hydrothermal activity is concentrated along the northwestern rim of the caldera, with white fluids venting through fissures and talus along the caldera wall, at a depth of about $1900 \mathrm{~m}$. The entire area $(400 \mathrm{~m}$ in diameter) is covered with native sulphur and partially colonized by Vestimentifera worms associated with white bacterial mats, mussels, shrimps and galathean crabs. Shimmering white smokers give rise to a $\mathrm{pH}$ anomaly above the vents in the water column, as previously reported by Gamo et al. (1993). The fluids have moderate temperatures $\left(87\right.$ to $118^{\circ} \mathrm{C}$ ), with a very low $\mathrm{pH}$ (around 2.1) and a high $\mathrm{H}_{2} \mathrm{~S}$ content up to $9.6 \mathrm{mmol} / \mathrm{kg}$. Silica concentrations are low, between 3 and $5.82 \mathrm{mmol} / \mathrm{kg}$, with high $\mathrm{SO}_{4}$ and $\mathrm{Mg}$ concentrations of $33 \mathrm{mmol} / \mathrm{kg}$ and 48 to $53 \mathrm{mmol} / \mathrm{kg}$ respectively. This peculiar chemical composition contrasts with typical hydrothermal fluid compositions, and points to a shallow hydrothermal circulation with a direct influence by magmatic volatiles with little inferred modification by fluid-rock interaction
(Gamo et al., 1997).

The Pacmanus hydrothermal field $\left(3^{\circ} 43.6^{\prime} \mathrm{S}\right.$, $151^{\circ} 40.3^{\prime} \mathrm{E}$ ) lies at a depth of $\sim 1700 \mathrm{~m}$, close to the topographic high of the $20 \mathrm{~km}$ long Pual Ridge, a dacitic volcanic edifice that runs parallel to the axial rift. The site, which is largely colonized by hydrothermal fauna, comprises both fissure zones expelling warm shimmering waters $\left(30^{\circ} \mathrm{C}\right)$ and more active areas with small $(2-3 \mathrm{~m}$ high) anhydrite and tall (10-20 $\mathrm{m}$ high) sulfide and silica chimneys expelling hot, grey-black fluids up to $268^{\circ} \mathrm{C}$. Chemical analysis of the Pacmanus fluids shows that they are closer to the usual composition of mid-ocean ridge hydrothermal fluids than those of the Desmos site, with a $\mathrm{pH}$ between 2.7 and 3.4 and a silica content up to $15 \mathrm{mmol} /$ $\mathrm{kg}$.

The Susu site $\left(3^{\circ} 48^{\prime} \mathrm{S}, 152^{\circ} 05^{\prime} \mathrm{E}\right)$ is made up of three hydrothermally active volcanic mounds (called Suzette, North-Su and South-Su), approximately aligned in a northwest-southeast direction. Hydrothermal vents emit fluids between $50^{\circ} \mathrm{C}$ (South-Su) and $220-280^{\circ} \mathrm{C}$ (Suzette and North-Su) near the top of the mounds $(\sim 1350 \mathrm{~m})$, and are characterized by intense alteration of the volcanic rocks and young sulphur deposits. Associated hydrothermal fauna consists of clams and gasteropods.

\section{The Manus Spreading Center (MSC)}

The MSC displays a morphology similar to mid-ocean ridges, with a well developed spreading axis. The Vienna Woods hydrothermal site $\left(3^{\circ} 09.78^{\prime} \mathrm{S}, 150^{\circ} 16.7^{\prime} \mathrm{E}\right)$, previously explored by the Russian MIR submersible (Lisitsyn et al., 1993), lies at a water depth of $2500 \mathrm{~m}$ in the northeastern part of the ridge, where a drastic change occurs in the ridge morphology from a dome-shape axis to a central graben, $2-3 \mathrm{~km}$ wide and $200 \mathrm{~m}$ deep, with steep walls. The axial part of the graben is cut by a neovolcanic ridge. The area shows alternation of lobated lavas, lava tubes and pillows. The Vienna Woods hydrothermal area is located in the most fractured zone. It is a 

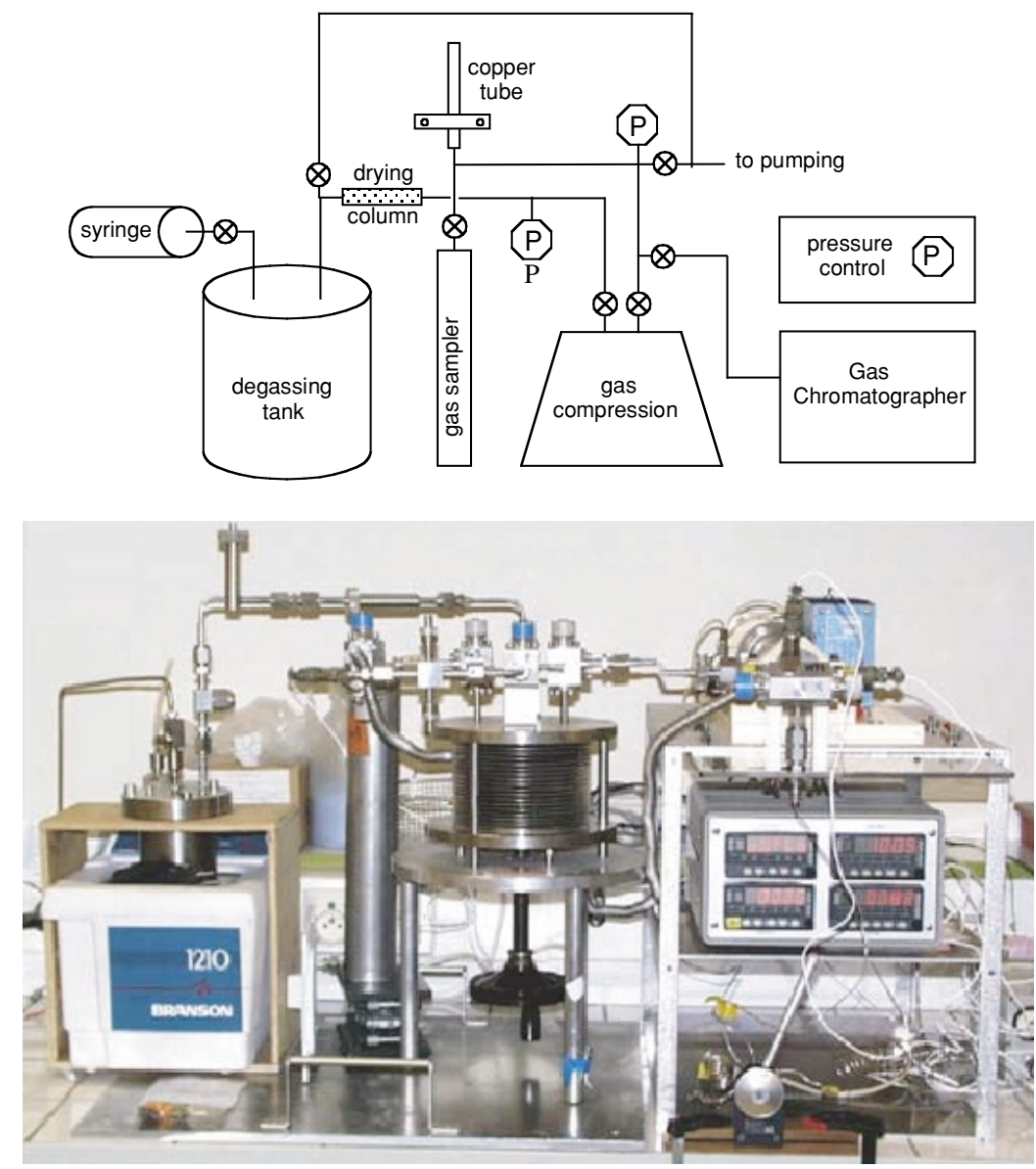

Fig. 2. Schematic diagram and photograph of the gas extraction line.

large field of active and extinct chimneys, about $300 \mathrm{~m}$ in diameter. The most active part of the site displays a spectacular concentration of chimneys, 10 to $15 \mathrm{~m}$ high, located on the top of a sulfide mound. The temperature of the fluids is very high (up to $300^{\circ} \mathrm{C}$ ). Their chemistry is unusual, with a slightly high $\mathrm{pH}$ (4.0 to 4.5$)$, low concentrations of $\mathrm{H}_{2} \mathrm{~S}$ (less than $2.0 \mathrm{mmol} / \mathrm{kg}$ ), and high silica (14 to $16 \mathrm{mmol} / \mathrm{kg}$ ) contents.

\section{The Western Spreading Rift (WSR)}

The WSR is an active spreading system. It is characterized by two shallow ridges propagating to the southwest and flanked by numerous active volcanos (Auzende et al., 2000). Both axes display fresh lava with vesicular glassy rocks and pumice. In spite of intense Mn anomalies recorded by the in situ analyser mounted on the Nautile, no hydrothermal site was discovered during five dives, except on the Mata $\mathrm{Na}$ Kul volcano $\left(2^{\circ} 58^{\prime} \mathrm{S}\right.$, $\left.147^{\circ} 08^{\prime} \mathrm{E}\right)$. Here, shimmering waters $\left(28-30^{\circ} \mathrm{C}\right)$ were observed and sampled at a depth of $1050 \mathrm{~m}$, associated with thick bacterial mats.

\section{METHODS}

\section{Sample collection}

Water samples were collected in two different ways: on the Manusflux cruise, the fluids were collected using a manifold-pump sampling system (Ishibashi et al., 1994) mounted on the Shinkai submersible. On the ship deck, the water was directly transferred through tygon tubing to a $3 / 8^{\prime \prime}$ copper tube equipped with clamps at both ends. In the laboratory, each tube was attached to a high vaccuum extraction line to transfer helium into a small glass bulb for subsequent mass spectrometry analysis. Unfortunately, this sampling protocol does not ensure a full recovery of the gases since some gas may be lost through the open end of the $\mathrm{Cu}$-tube during the transfer. This is apparent when comparing the 1995 and 2000 results for the Vienna Woods site (see the data evaluation section below).

During the Manaute cruise, vent samples were collected in 750-ml gas-tight titanium syringes (Charlou et al., 1996). These sampling devices, developed at 
Table 1. Manus Basin vent fluid helium isotopes data (the uncertainty in the ${ }^{3} \mathrm{He} /{ }^{4} \mathrm{He}$ value is within $\pm 0.05 R_{a}$, with a relative error in the helium concentration $<5 \%$ )

\begin{tabular}{|c|c|c|c|c|c|c|c|}
\hline Site & Sample reference & Vent type & $\begin{array}{c}\mathrm{T} \\
\left({ }^{\circ} \mathrm{C}\right)\end{array}$ & $\mathrm{pH}$ & $\begin{array}{l}\text { Helium concentration } \\
(\mathrm{nmol} / \mathrm{kg})\end{array}$ & $\mathrm{R} / \mathrm{R}_{\mathrm{a}}$ & $\begin{array}{c}\mathrm{Mg} \\
(\mathrm{mmol} / \mathrm{kg})\end{array}$ \\
\hline DESMOS & PL04G2 & diffuse & 9 & 5.02 & 29.3 & 1.78 & 47.5 \\
\hline \multirow[t]{3}{*}{ SUZETTE } & PL01D2 & smoker & 240 & 4.53 & 507.1 & 7.39 & 15.4 \\
\hline & PL01G2 & smoker & 262 & 3.87 & 538.4 & 7.14 & 8.1 \\
\hline & PL02G3 & smoker & 227 & 3.87 & 970.5 & 7.38 & 9.5 \\
\hline \multirow[t]{2}{*}{ NORTH-SU } & PL02G1 & smoker & 90 & 5.74 & 69.8 & 6.82 & 35.8 \\
\hline & PL02D2 & smoker & 240 & 4.31 & 348.3 & n.d. & 21.4 \\
\hline \multirow[t]{7}{*}{ PACMANUS } & $297-3$ & black smoker & 165 & 5.81 & 7.4 & 5.95 & 47.6 \\
\hline & $299-1$ & plume & 6 & 7.26 & 3.1 & 2.25 & 52.7 \\
\hline & $299-3$ & plume & 6 & 7.08 & 2.3 & 2.25 & 51.9 \\
\hline & $301-3$ & black smoker & 252 & 3.08 & 41.2 & 7.76 & 22.0 \\
\hline & $301-5$ & grey smoker & 268 & 2.87 & 57.6 & 7.77 & 27.0 \\
\hline & $301-8$ & grey smoker & 268 & 2.63 & 91.5 & 7.73 & 23.5 \\
\hline & $304-3$ & diffuse & 142 & 5.57 & 17.0 & 6.90 & 37.9 \\
\hline \multirow[t]{10}{*}{ VIENNA WOODS } & $303-\mathrm{Ni}-2$ & plume (+5 m) & - & 7.37 & 1.9 & 1.75 & 52.6 \\
\hline & $303-\mathrm{Ni}-3$ & plume $(+10 \mathrm{~m})$ & - & 7.43 & 3.5 & 6.90 & 52.7 \\
\hline & 303-Ti-2 & clear smoker & & 6.19 & 71.9 & 11.28 & 42.7 \\
\hline & $303-3$ & clear smoker & $\begin{array}{l}249 \\
251\end{array}$ & 5.16 & 176.8 & 11.32 & 16.8 \\
\hline & $303-5$ & grey smoker & $\begin{array}{l}251 \\
300\end{array}$ & 4.50 & 225.0 & 11.19 & 3.7 \\
\hline & $307-3$ & white smoker & 300 & 4.52 & 270.5 & 11.15 & 2.6 \\
\hline & $308-3$ & white smoker & $\begin{array}{l}262 \\
282\end{array}$ & 4.16 & 267.0 & 11.16 & 1.2 \\
\hline & PL07G1 & smoker & $\begin{array}{l}282 \\
292\end{array}$ & 4.80 & 369.5 & 11.94 & 1.6 \\
\hline & PL07G2 & smoker & $\begin{array}{l}292 \\
291\end{array}$ & 4.42 & 418.3 & 11.36 & 2.4 \\
\hline & PL07G3 & smoker & $\begin{array}{l}291 \\
264\end{array}$ & 4.94 & 398.7 & 11.85 & 4.7 \\
\hline \multirow[t]{2}{*}{ MATA NA KUL } & PL10D1 & diffuse & 8 & 6.40 & 87.9 & 3.31 & 46.2 \\
\hline & PL10G1 & diffuse & 28 & 6.12 & 824.6 & 7.44 & 46.9 \\
\hline Pacific deep waters & & & & & 1.7 & 1.15 & 53.0 \\
\hline
\end{tabular}

References starting with the letters "PL" correspond to the 2000 Manaute samples. All other references correspond to the 1995 Manusflux samples which are likely to have suffered from partial degassing during sampling (see text).

IFREMER specifically for the french submersibles Cyana and Nautile, have been used routinely since the early 80 's for hydrothermal gas studies. On the ship deck, the fluid samples were transferred in a specially designed evacuated degassing tank ensuring 100\% gas recovery (Charlou et al., 2000, 2004). During the transfer procedure, the syringes were kept under water to avoid any helium contamination by air. The degassing tank (Fig. 2) is a refinement of the prototype used in previous studies (JeanBaptiste et al., 1991). The main improvement consists in the addition of a compression unit which ensures the complete transfer of the dissolved species from the degassing tank to a small stainless steel container through a drying column. The pressure in various parts of the equipment is monitored by miniature digital sensors. In parallel with the stainless steel container, a gas aliquot $\left(2.5 \mathrm{~cm}^{3}\right)$ is also taken in a small copper tube for the helium isotopes analysis. This tube is closed at one end by a braised stain- less steel stopper and can be tightly sealed at the open end with a special clamp.

\section{Analytical procedure}

In the laboratory, the samples (either the glass bulbs or the copper tubes) are connected to the inlet system of a VG-3000 mass spectrometer for isotopic analysis. Analytical details are given in Jean-Baptiste et al. (1992). In short, the gas samples are introduced in the mass spectrometer through a series of traps (a water trap and a charcoal trap, both in liquid nitrogen, and a Ti-getter to remove hydrogen). Owing to the large amount of helium stored in the copper tubes, the gas is first expanded into a calibrated volume from which small aliquots $(0.12 \mathrm{cc})$ are injected in the inlet system. The ${ }^{3} \mathrm{He}$ blank of the line is negligible $\left(<10^{-19}\right.$ mole). ${ }^{4} \mathrm{He}$ is measured on a Faraday cup. ${ }^{3} \mathrm{He}$ is detected by ion counting using an electron multiplier. The uncertainty in the individual isotopic 
Table 2. Helium isotope end-member compositions. The Mata Na Kul values are minimum values due to the impossibility of applying the regression to $M g=0$ method (see text). Other minimum estimates relate to the 1995 samples which are likely affected by partial gas loss during sampling.

\begin{tabular}{lccccc}
\hline Site & $\begin{array}{c}\text { Tmax } \\
\left({ }^{\circ} \mathrm{C}\right)\end{array}$ & $\begin{array}{c}{ }^{4} \mathrm{He} \text { end-member } \\
(\mathrm{nmol} / \mathrm{kg})\end{array}$ & $\begin{array}{c}{ }^{3} \mathrm{He} /{ }^{4} \mathrm{He} \\
\left(\mathrm{R} / \mathrm{R}_{\mathrm{a}}\right)\end{array}$ & $\begin{array}{c}{ }^{3} \mathrm{He} \text { end-member } \\
(\mathrm{pmol} / \mathrm{kg})\end{array}$ & $\begin{array}{c}{ }^{3} \mathrm{He} / \mathrm{Heat} \\
\left(10^{-18} \mathrm{~mol} / \mathrm{J}\right)\end{array}$ \\
\hline DESMOS (1995) & 118 & & $8^{*}$ & & \\
SUZETTE/NORTH SU (2000) & 280 & $900 \pm 300$ & $7.4 \pm 0.1$ & $9 \pm 3$ & $7.6 \pm 2.5$ \\
PACMANUS (1995) & 268 & $>120$ & $7.9 \pm 0.1$ & $>1.3$ & $>1$ \\
PACMANUS (1995) & & & $7.4^{*}$ & & $>2.9$ \\
VIENNA WOODS (1995) & 300 & $>275$ & $11.3 \pm 0.1$ & $>4.3$ & \multicolumn{2}{c}{$4.8 \pm 0.3$} \\
VIENNA WOODS (1995) & & & $12^{*}$ & \\
VIENNA WOODS (2000) & 300 & 420 & $12.0 \pm 0.1$ & $7.0 \pm 0.4$ & $\geq 80$ \\
MATA NA KUL (2000) & 30 & $\geq 825$ & $7.4 \pm 0.1$ & $\geq 8.4$ & \multicolumn{2}{c}{} \\
\hline
\end{tabular}

*Ishibashi et al. (1996).

ratio is within $-0.05 R_{a}$, with a relative error in the total helium concentration $<5 \%\left(\mathrm{R}_{\mathrm{a}}\right.$ is the atmospheric ${ }^{3} \mathrm{He} /$ ${ }^{4} \mathrm{He}$ ratio).

\section{RESULTS}

\section{Data evaluation}

The end-member ${ }^{3} \mathrm{He} /{ }^{4} \mathrm{He}$ value for each site is deduced from the slope of linear relationship linking both isotopes. ${ }^{3} \mathrm{He}$ end-member concentrations are estimated from the plot of the ${ }^{3} \mathrm{He}$ concentration in the vent fluids against $\mathrm{Mg}$, which indicates the degree of dilution by ambient seawater. In contrast to the absence of Mg in typical hydrothermal end-member fluids, those fluids expelled by the Desmos and Mata Na Kul volcanoes are rich in $\mathrm{Mg}$. This indicates a secondary $\mathrm{Mg}$ source, most likely derived by the acidic dissolution of magnesium-bearing silicates according to the reaction $\mathrm{Mg}_{2} \mathrm{SiO}_{4}+4 \mathrm{H}^{+} \rightarrow$ $2 \mathrm{Mg}^{2+}+\mathrm{SiO}_{2}+\mathrm{H}_{2} \mathrm{O}$ (Gamo et al., 1997). In this case, the method of back calculating to an endmember fluid where $\mathrm{Mg}=0$ is no longer applicable and the only thing that can be determined is a lower limit to the helium endmember concentration, which equals the concentration in the most enriched sample.

For the 1995 samples, an additional problem arises from the sampling procedure which did not ensure a $100 \%$ gas recovery (see above). The Vienna Woods site, which was sampled both in 1995 and in 2000, shows that the 1995 end-member concentration is $\sim 65 \%$ below that determined in 2000 . The ${ }^{3} \mathrm{He} /{ }^{4} \mathrm{He}$ value also appears to be affected, with the 1995 value $~ 6 \%$ below the 2000 value, probably due to isotopic fractionation and preferential loss of the lighter isotope. However, the samples drawn from the same syringes by the Japanese team (Ishibashi et al., 1996) do not show any sign of fractionation, with a ${ }^{3} \mathrm{He} /$ ${ }^{4} \mathrm{He}$ ratio in good agreement with our 2000 value $(=12$ $\mathrm{R}_{\mathrm{a}}$ ). As the Japanese Vienna Woods samples were drawn from the samplers first, we suggest that the gas loss prob- lem is not very important if the samples are taken immediately after the opening of the syringe but becomes more severe after that. The 1995 sampling procedure is thus problematic, therefore the 1995 results must be considered as lower limits.

\section{Helium isotopes results}

Table 1 presents the helium abundance and isotopic $\left({ }^{3} \mathrm{He} /{ }^{4} \mathrm{He}\right)$ data for the hydrothermal fluids collected from the various locations described above. The measured ratios range from values slightly below or close to $8 R_{a}$ on the WSR $\left(7.4 \mathrm{R}_{\mathrm{a}}\right.$ ) and on the SER (7.4 to $7.9 \mathrm{R}_{\mathrm{a}}$ ), to $12 \pm$ $0.1 \mathrm{R}_{\mathrm{a}}$ for the Vienna Woods site on the MSC (Fig. 3). The ${ }^{3} \mathrm{He}$ end-member concentration at Vienna Woods (2000) and Suzette sites (Table 2) are $7 \pm 0.4 \mathrm{pmol} / \mathrm{kg}$ and $9 \pm 3 \mathrm{pmol} / \mathrm{kg}$, respectively. These values are on the lower end of the range for concentrations reported for known hydrothermal sites, between $9.2 \pm 3$ and $25 \pm 5$ pmol/kg (Jean-Baptiste et al., 2004). The lower bound for the ${ }^{3} \mathrm{He}$ end-member concentration in the fluids from the Mata $\mathrm{Na} \mathrm{Kul} \mathrm{volcano} \mathrm{is} \mathrm{of} \mathrm{similar} \mathrm{concentration} \mathrm{(8.4}$ $\mathrm{pmol} / \mathrm{kg}$ ). The Pacmanus value is much lower $(1.3 \mathrm{pmol} /$ $\mathrm{kg}$ ) but probably underestimated due to gass loss when sampling.

${ }^{3} \mathrm{He} /$ heat values for the Susu and Vienna Woods sites (Table 2) are $(6.6 \pm 2.5) \times 10^{-18}$ and $(4.8 \pm 0.3) \times 10^{-18}$ $\mathrm{mol} / \mathrm{J}$, respectively. Although the sites are located in a back-arc environment, these values are comparable to those observed at various sites on the Mid-Atlantic Ridge and on the East Pacific Rise (Lupton et al., 1999; JeanBaptiste et al., 2004). The ratio measured at Pacmanus is lower $\left(1 \times 10^{-18} \mathrm{~mol} / \mathrm{J}\right)$, again most likely because of ${ }^{3} \mathrm{He}$ loss during sampling. The ${ }^{3} \mathrm{He} /$ heat value observed at the Mata $\mathrm{Na} \mathrm{Kul} \mathrm{volcano} \mathrm{is} \mathrm{much} \mathrm{higher}\left(>80 \times 10^{-18} \mathrm{~mol} /\right.$ J). It corresponds to the values measured over fresh lava flows at the Juan de Fuca Spreading center ( 22 to $75 \times$ $10^{-18} \mathrm{~mol} / \mathrm{J}$ ), which are characteristics of immature hydrothermal systems (Lupton et al., 1999). 

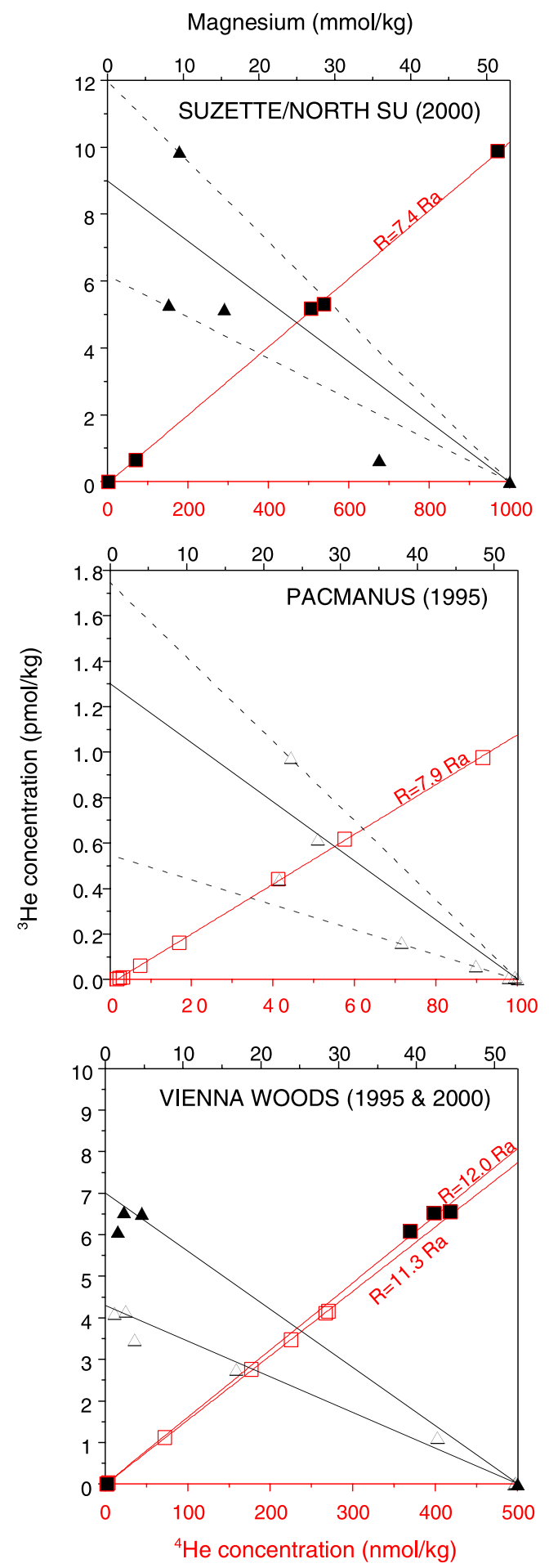

Fig. 3. ${ }^{3} \mathrm{He}-{ }^{4} \mathrm{He}$ (in red) and ${ }^{3} \mathrm{He}-\mathrm{Mg}$ relationships in the vent fluids. The open and filled symbols correspond to the 1995 and 2000 data sets, respectively.

\section{DISCUSSION}

The ${ }^{3} \mathrm{He} /{ }^{4} \mathrm{He}$ value for hydrothermal fluids, averaged over the mid-ocean ridge sites where helium isotopes data are available (Jean-Baptiste et al., 2004), occurs in a very narrow range of $8.0 \pm 0.5 \mathrm{R}_{\mathrm{a}}$, in line with MORB ${ }^{3} \mathrm{He} /$ ${ }^{4} \mathrm{He}$ data, where the vast majority range $7-9 \mathrm{R}_{\mathrm{a}}$. The helium isotope composition of the samples collected on the SER and WSR are on the lower side of the MORB range, in agreement with values observed elsewhere in areas influenced by subduction processes (e.g., Poreda and Craig, 1989). By contrast, the ${ }^{3} \mathrm{He} /{ }^{4} \mathrm{He}$ value for Vienna Woods (MSC) is significantly higher. This result is in excellent agreement with ${ }^{3} \mathrm{He} /{ }^{4} \mathrm{He}$ data from rock samples (Macpherson et al., 1998) which also show elevated ${ }^{3} \mathrm{He} /{ }^{4} \mathrm{He}$ ratio of $12 \pm 1 \mathrm{R}_{\mathrm{a}}$ for lavas from the Manus Spreading Center. Both data sets, combined with available data for nearby volcanic islands, indicate that these elevated ${ }^{3} \mathrm{He} /{ }^{4} \mathrm{He}$ values are confined to the central part of the Manus Basin, with no evidence of above MORB values beyond the MSC. Hydrothermal fluids from the WSR and SER, as well as glasses and geothermal gases from Witu islands (Macpherson et al., 1998) and from the Tabar-Lihir-Tanga-Feni islands (Patterson et al., 1997), located approximately $300 \mathrm{~km}$ to the north-east and $150 \mathrm{~km}$ to the south of the MSC, respectively, have ${ }^{3} \mathrm{He} /{ }^{4} \mathrm{He}$ values overlapping, or below, those of MORB range.

The spatial distribution of the helium isotope anomaly has been discussed by Macpherson et al. (1998) in terms of a focussed mantle plume upwelling transferring high ${ }^{3} \mathrm{He} /{ }^{4} \mathrm{He}$ material from the deep mantle to the surface. These authors argue that the Manus Basin coincides with a region of low seismic wave velocities in the $\mathrm{D}^{\prime \prime}$ layer above the core-mantle boundary (Van der Hilst et al., 1997), thus providing a possible link between geodynamics and the helium isotope anomaly. However, the spatial extent of this deep P-wave-speed anomaly is much broader than the Manus Basin Spreading Center, covering most of the Western Pacific with a deep root beneath the Coral sea, with a weak connection to a second anomaly beneath the East Salomon (Montelli et al., 2004). Furthermore, the back-arc basin is probably shielded from any deep plume influence by the subducting slab. Therefore, the causal link between this broad western Pacific geophysical anomaly and the narrow spatial extent of the ${ }^{3} \mathrm{He} /{ }^{4} \mathrm{He}$ anomaly at the MSC remains rather inconclusive.

Alternatively, the limited spatial extent of the ${ }^{3} \mathrm{He} /{ }^{4} \mathrm{He}$ anomaly may be a case for small scale upper-mantle heterogeneity distributed throughout the mantle (Meibom and Anderson, 2003) and sampled to various extents by partial melting at spreading centers and oceanic islands. Over the last 30 years, the prevailing view among geochemists has been that the high ${ }^{3} \mathrm{He} /{ }^{4} \mathrm{He}$ values are associated with 
deep-rooted plumes originating from a primordial ${ }^{3} \mathrm{He}$ rich reservoir isolated from the well-mixed upper mantle (Allègre et al., 1983). This "standard" model has come under increasing scrutiny since tomographic seismic images have shown that subducted slabs are capable of sinking through the $660 \mathrm{~km}$-discontinuity deep into the lower mantle (Van der Hilst et al., 1997). The alternative wholemantle-convection model also benefited from recent advances in numerical modeling of mantle convection which suggests that separately convecting, isolated, lower and upper mantle is not a realistic option. The doubts cast over the standard geochemical model by geophysicists is further reinforced by the lack of correlation between high ${ }^{3} \mathrm{He} /{ }^{4} \mathrm{He}$ anomalies and the maximum depth of the plume seismic images (Zhao, 2001; Montelli et al., 2004). That is, whereas some high ${ }^{3} \mathrm{He} /{ }^{4} \mathrm{He}$ values actually correspond to well-resolved deep plumes, others like the Yellowstone hotspot, correspond to regions where a deep origin can be ruled out (Christiansen et al., 2002).

Answering the question of whether or not helium isotopic signature can be used as a reliable tracer of the deep mantle involvement in magmatic processes is beyond the scope of the present note. Moreover, ongoing debate shows that acquiring more data worldwide on isotope geochemistry, including helium isotopes, is central to improve our current understanding of mantle processes.

\section{Conclusion}

Hydrothermal fluids were sampled at several locations along the three ridges which strike from east to west across the Manus Basin. On the SER and WSR, the helium isotope composition of the fluids is consistent with that measured elsewhere in comparable subduction environments, with ${ }^{3} \mathrm{He} /{ }^{4} \mathrm{He}$ values in the range $7.4 \mathrm{R}_{\mathrm{a}}$ to $7.9 \mathrm{R}_{\mathrm{a}}$. The fluids from the Mata $\mathrm{Na}$ Kul volcano $\left(7.4 \mathrm{R}_{\mathrm{a}}\right.$ ) show an elevated ${ }^{3} \mathrm{He} / \mathrm{heat}$ value $\left(>80 \times 10^{-18} \mathrm{~mol} / \mathrm{J}\right)$ similar to those recorded in Juan de Fuca over fresh lava flows, and are indicative of a young hydrothermal system.

The ${ }^{3} \mathrm{He} /{ }^{4} \mathrm{He}$ value measured at Vienna Woods (MSC) is significantly higher $\left(12 \pm 0.1 \mathrm{R}_{\mathrm{a}}\right)$. This result is in excellent agreement with ${ }^{3} \mathrm{He} /{ }^{4} \mathrm{He}$ data from lava samples reported by Macpherson et al. (1998) which also show elevated ${ }^{3} \mathrm{He} /{ }^{4} \mathrm{He}$ ratios of $12 \pm 1 \mathrm{R}_{\mathrm{a}}$. A few years ago we would have concluded, based on the high ${ }^{3} \mathrm{He} /{ }^{4} \mathrm{He}$ value, that there is involvement of deep mantle in the MSC system. However, recent geophysical results have pointed to the lack of correlation between high ${ }^{3} \mathrm{He} /{ }^{4} \mathrm{He}$ anomalies and the maximum depth of plume seismic images for a number of well documented "high helium-3" hotspots (Zhao, 2001; Montelli et al., 2004). In the absence of any convincing geophysical evidence for a deep mantle connection, the limited spatial extent of the ${ }^{3} \mathrm{He} /{ }^{4} \mathrm{He}$ anomaly in the Manus basin may indeed be an argument in favour of the upper-mantle heterogeneity theory (Meibom and Anderson, 2003).

Acknowledgments - The authors wish to thank G. Winckler and one anonymous reviewer for their constructive comments. The authors also thank C. de Ronde for the editorial handling of this manuscript and for his suggestions which helped improve the clarity of the paper.

\section{REFERENCES}

Allègre, C. J., Staudacher, T., Sarda, P. and Kurz, M. D. (1983) Constraints on evolution of Earth mantle from rare gas systematics. Nature 303, 762-766.

Auzende, J. M., Ishibashi, J. I., Beaudoin, Y., Charlou, J. L., Delteil, J., Donval, J. P., Fouquet, Y., Ildefonse, B., Kimura, H., Nishio, Y., Radford-Knoery, J. and Ruellan, E. (2000) Extensive magmatic and hydrothermal activity documented in Manus Basin. EOS, Trans. Am. Geophys. Union 81(39), 449-453.

Binns, R. A. and Scott, S. D. (1993) Actively forming polymetallic sulfides deposits associated with felsic volcanic rocks in the Eastern Manus Back-Arc Basin, Papua New Guinea. Econ. Geol. 88, 2226-2236.

Charlou, J. L., Fouquet, Y., Donval, J. P., Auzende, J. M., JeanBaptiste, P., Stievenard, M. and Michel, S. (1996) Mineral and gas chemistry of hydrothermal fluids on an ultrafast spreading ridge: East Pacific Rise, $17^{\circ} \mathrm{S}$ to $19^{\circ} \mathrm{S}$ (Naudur cruise)-Phase separation processes controlled by volcanic and tectonic activity. J. Geophys. Res. 101, 15899-15919.

Charlou, J. L., Donval, J. P., Douville, E., Jean-Baptiste, P., Radford-Knoery, J., Fouquet, Y., Dapoigny, A. and Stievenard, M. (2000) Compared geochemical signatures and evolution of Menez Gwen $\left(37^{\circ} 50 \mathrm{~N}\right)$ and Lucky Strike $\left(37^{\circ} 17 \mathrm{~N}\right)$ hydrothermal fluids, south of the Azores Triple junction on the Mid-Atlantic Ridge. Chem. Geol. 171, 4975.

Charlou, J. L., Donval, J. P., Fouquet, Y., Ondreas, H., Cochonat, P., Levaché, D., Poirier, Y., Jean-Baptiste, P., Fourré, E., Chazallon, B. and the ZAIROV leg2 Scientific Party (2004) Gas hydrates in the Congo-Angola Basin: physical and geochemical characteristics. Chem. Geol. 205, 405-425.

Christiansen, R. L., Foulger, G. R. and Evans, J. R. (2002) Upper-mantle origin of the Yellowstone hotspot. Geol. Soc. Am. Bull. 114, 1245-1256.

Craig, H., Craig, V. K. and Kim, K. R. (1987) PAPATUA Expedition I: Hydrothermal vent surveys in back-arc basins: the Lau, N. Fiji, Woodlark and Manus basins and Havre trough. EOS, Trans. Am. Geophys. Union 68(7), 100 (abstract).

Gamo, T., Sakai, H., Ishibashi, J. I., Nakayama, E., Isshiki, K., Matsuura, H., Shitashima, K., Takeuchi, K. and Ohta, S. (1993) Hydrothermal Plumes in the Eastern Manus Basin, Bismarck Sea: $\mathrm{CH}_{4}, \mathrm{Mn}, \mathrm{Al}$ and $\mathrm{pH}$ anomalies. Deep-Sea Res. 40, 2335-2349.

Gamo, T., Okamura, K., Urabe, T., Auzende, J. M., Ishibashi, J. I., Shitashima, K. and Chiba, H. (1997) Acidic and sulfaterich hydrothermal fluids from the Manus back-arc basin, Papua New Guinea. Geology 25, 139-142. 
Ishibashi, J. I., Wakita, H., Nojiri, Y., Grimaud, D., JeanBaptiste, P., Gamo, T., Auzende, J. M. and Urabe, T. (1994) Helium and carbone geochemistry of hydrothermal fluids from the North Fiji basin spreading ridge (Southern Pacific). Earth Planet. Sci. Lett. 128, 183-197.

Ishibashi, J. I., Okamura, K., Shitashima, K., Charlou, J. L. and Jean-Baptiste, P. (1996) Chemical characteristics of hydrothermal fluids from the Manus back-arc basin, Papua New Guinea, II. Gas components. Western Geophysics meeting. EOS, Trans. Am. Geophys. Union 76, W116 (abstract).

Jean-Baptiste, P., Charlou, J. L., Stievenard, M., Donval, J. P., Bougault, H. and Mevel, C. (1991) Helium and methane measurements in hydrothermal fluids from the Mid Atlantic Ridge: the SNAKE PIT site at $23^{\circ}$ N. Earth Planet. Sci. Lett. 106, 17-28.

Jean-Baptiste, P., Mantisi, F., Dapoigny, A. and Stievenard, M. (1992) Design and performance of a mass spectrometric facility for measuring helium isotopes in natural waters and for low-level tritium determination by the ${ }^{3} \mathrm{He}$ ingrowth method. Appl. Radiat. Isot., Int. J. Radiat. Appl. Instrum. Part A, 43(7), 881-891.

Jean-Baptiste, P., Fourré, E., Charlou, J. L., German, C. and Radford-Knoery, J. (2004) Helium isotopes at the Rainbow hydrothermal site (MAR, $\left.36^{\circ} 14 \mathrm{~N}\right)$. Earth Planet. Sci. Lett. 221, 325-335.

Lisitsyn, A. P., Crook, K. A. W., Bogdanov, Y. A., Zonenshayn, L. P., Murav, K. G., Tufar, W., Gurvich, Y. G., Gordeyev, V.
V. and Ivanov, G. V. (1993) A hydrothermal field in the rift zone of the Manus basin, Bismarck sea. Int. Geol. Review 35, 105-126.

Lupton, J. E., Baker, E. T. and Massoth, G. J. (1999) Helium, heat, and the generation of hydrothermal event plumes at mid-ocean ridges. Earth Planet. Sci. Lett. 171, 343-350.

Macpherson, C. G., Hilton, D. R., Sinton, J. M., Poreda, R. and Craig, H. (1998) High ${ }^{3} \mathrm{He} /{ }^{4} \mathrm{He}$ ratios in the Manus backarc basin: implications for mantle mixing and the origin of plumes in the western Pacific Ocean. Geology 26, 10071010.

Meibom, A. and Anderson, D. L. (2003) The statistical upper mantle assemblage. Earth Planet. Sci. Lett. 217, 123-139.

Montelli, R., Nolet, G., Dahlen, F. A., Masters, G., Engdahl, E. R. and Hung, S. H. (2004) Finite-frequency tomography reveals a variety of plumes in the mantle. Nature 303, 338343.

Patterson, D. B., Farley, K. A. and McInnes, B. I. (1997) Helium isotopic composition of the Tabar-Lihir-Tanga-Feni island arc, Papua New Guinea. Earth Planet. Sci. Lett. 61, 2485-2496.

Poreda, R. and Craig, H. (1989) Helium isotope ratios in circumPacific volcanic arcs. Nature 338, 473-478.

Van der Hilst, R. D., Widiyantoro, S. and Engdahl, E. R. (1997) Evidence for deep mantle circulation from global tomography. Nature 386, 578-584.

Zhao, D. (2001) Seismic structure and origin of hotspots and mantle plumes. Earth Planet. Sci. Lett. 192, 251-265. 